Elsevier

BBA 74170

\title{
The effect of calmodulin on the interaction of carbodiimides with the purified human erythrocyte $\left(\mathrm{Ca}^{2+}+\mathrm{Mg}^{2+}\right)-\mathrm{ATPase}$
}

\author{
Olufunso O. Olorunsogo *, Antonio Villalobo, Kevin K.W. Wang \\ and Basil D. Roufogalis
}

Facuity of Pharmaceutical Sciences, University of British Columbia, Vancouver (Canada)

(Received 15 February 1988)

Key words: Calmodulin; Carbodiimide; ATPase, $\left(\mathrm{Ca}^{2+}+\mathrm{Mg}^{2+}\right)$-; Erythrocyte: (Human)

The activity of the solubilized and purified $\left(\mathrm{Ca}^{2+}+\mathrm{Mg}^{2+}\right)$-ATPase from human erythrocyte membranes was inhibited by $N, N^{\prime}$-dicyclohexylcarbodiimide in a concentration-dependent manner. The carbodiimide prevented formation of the phosphorylated intermediate during the catalytic cycle of the enzyme. Treatment of the enzyme with $N, N^{\prime}$-dicyclohexyl| ${ }^{14}$ C|carbodimide resulted in the formation of a ${ }^{14} \mathrm{C}$-labelled polypeptide corresponding to the enzyme monomer (molecular weight 136000). The tryptic fragmentation of this ${ }^{14} \mathrm{C}$-labelled enzyme resulted in the formation of three major ${ }^{14} \mathrm{C}$-labelled fragments with molecular weights of 58000,36500 and 23000 , the latter two probably representing transmembrane and calmodulinbinding domains of the enzyme, respectively. In the absence of calmodulin, 6.7 molecules of $N, N^{\prime}$-dicyclohexyll ${ }^{14} \mathrm{Clcarbodiimide}$ covalently bound to each molecule of $\mathrm{Ca}^{2+}$-ATPase; in the presence of calmodulin, the number of molecules of carbodimide bound was 13.1. The binding of $N, N^{\prime}$-dicyclohexylcarbodiimide to the $\left(\mathrm{Ca}^{2+}+\mathrm{Mg}^{2+}\right)$-ATPase greatly reduced its ability to bind to a calmodulin-agarose gel.

\section{Introduction}

$N, N^{\prime}$-Dicyclohexylcarbodiimide (DCCD) has been used as a carboxyl-modifying reagent to help understand the mechanism of operation of a series of enzymes involved in energy transduction (see

\footnotetext{
- Present address: Laboratory for Biomembrane Research, Department of Biochemistry, University of Ibadan. Ibadan, Nigeria.

Abbreviations: DCCD, $N, N^{\prime}$-dicyclohexylcarbodiimide; Hepes, 4-(2-hydroxyethyl)-1-piperazineethanesulfonic acid; EGTA, ethyleneglycol tis-( $\beta$-aminoethyl ether) $N, N, N^{\prime}, N^{\prime}$-tetraacetic acid; EDTA, ethylenediamine-tetraacetic acid.
}

Correspondence: A. Villalobo, Faculty of Pharmaceutical Sciences, University of British Columbia, 2146 East Mall, Vancouver, B.C., V6T 1W5, Canada.
Ref. 1 for a review), including systems involved in $\mathrm{H}^{+}$translocation . [2-11], $\mathrm{Ca}^{2+}$ translocation [12-16] and $\mathrm{Na}^{+}$and $\mathrm{K}^{+}$translocation [17-21]. Previous work in this laboratory has demonstrated that the solubilized and purified $\left(\mathrm{Ca}^{2+}+\mathrm{Mg}^{2+}\right)$ ATPase from human erythrocyte plasma membrane $[22,23]$ is strongly inhibited by the hydrophotic earbodimide DCCD. and to a much lesser extent by carbodiimides of lower degree of hydrophobicity [16]. This inhibition was favored by the binding of $\mathrm{Ca}^{2+}$ to the enzyme and was maximal at a slightly acid $\mathrm{pH}$ [16]. Furthermore, it was shown that calmodulin favors the $\mathrm{Ca}^{2+}$-dependent inactivation induced by this carbodiimide and that DCCD appears specifically to decrease the calmodulin-inciuced activation of the $\left(\mathrm{Ca}^{2+}+\right.$ $\left.\mathrm{Mg}^{2+}\right)$-ATPase without inactivating the calmodulin molecule itself [16]. We have further studied 
the inhibitory effect of DCCD on the $\left(\mathrm{Ca}^{2+}+\right.$ $\mathrm{Mg}^{2+}$ )-ATPase of human erythrocyte and demonstrated not only that the calmodulin-binding domain of the enzyme could be modified by DCCD, but that the binding of calmodulin to the enzyme dramatically increases the number of carbodiimide reactive groups in the enzyme.

\section{Materials and Methods}

Chemicals. $\quad N, N^{\prime}$-Dicylcohexyl $\left[{ }^{14} \mathrm{C}\right]$ carbodiimide ( $57 \mathrm{mCi} \cdot \mathrm{mmol}^{-1}$ ) was purchased from Amersham Canada (Montreal) and $\left[\gamma-{ }^{32}\right.$ P]ATP $\left(28.9 \mathrm{Ct} \cdot \mathrm{mmol}^{-1}\right)$ was from ICN Radiochemicals (Irvine, CA, U.S.A.). Bovine brain phosphodiesterase $3^{\prime}, 5^{\prime}$-cyclic nucleotide activatoragarose gei. Triton X-100, Hepes, ATP (disodium salt), trypsin (bovine pancreas, type III), DCCD and EGTA were obtained from Sigma Chemical Co. (St. Louis, MO, U.S.A.). Bovine brain calmodulin was obtained from Calbiochem ( $\mathrm{La}$ Jolla, CA, U.S.A.), and asolectin was purchased from MCB Manufacturing Chemical Inc. (Cincinnati, OH, U.S.A.). X-OMAT AR X-ray blue sensitive films were obtained from Kodak. All other chemicals used in this work were of analytical grade.

Preparation of calmodulin-depleted erythrocyte memibranes, solubilization and purification of the $\left(\mathrm{Ca}^{2+}+\mathrm{Mg}^{2+}\right)$-ATPase. The methods describing the preparation of calmodulin-depleted human erythrocyte membranes, tite suiuvilization and purification of the $\left(\mathrm{Ca}^{2+}+\mathrm{Mg}^{2+}\right)$-ATPase, have been described previously $[16,22]$. Photodensitometric scanning of three electrophoretic gels stained with Coomassie blue shows that the band of molecular weight 136000 representing the $\left(\mathrm{Ca}^{2+}+\mathrm{Mg}^{2+}\right)$-ATPase accounts for $91.3 \pm 1.5 \%$ of the total protein. A minor contaminant of molecular weight 97000 was also present. However, autoradiography of the $\left[{ }^{14} \mathrm{C}\right] \mathrm{DCCD}$-labelled preparations shows that this contaminant did not become labelled (see Fig. 1).

Measurement of the phosphorylated intermediate of the enzyme. The purified enzyme (5.2 $\mu \mathrm{g}$ protein) was incubated in $0.2 \mathrm{ml}$ at $4^{\circ} \mathrm{C}$ during $15 \mathrm{~s}$ in a medium containing $40 \mathrm{mM}$ potassium-Hepes, $0.1 \mathrm{mM} \mathrm{MgCl}_{2}, 0.92 \mathrm{mM} \mathrm{CaCl}, 2 \mathrm{mM}$ dithiothreitol, $0.054 \%(w / v)$ Triton X-100, 0.1\% (w/v) sonicated asolectin and $10 \mu \mathrm{M}$ ATP containing $\left[\gamma-{ }^{32} \mathrm{P}\right] \mathrm{ATP}\left(6 \mathrm{mCi} \cdot \mathrm{mmol}^{-1}\right)(\mathrm{pH} 7.4)$. The reaction was initiated by the addition of $\left[\gamma^{37}\right.$ P]ATP and terminated by the addition of ice-cold $10 \%$ (w/v) trichloroacetic acid. The precipitated protein was processed for electrophoresis at $\mathrm{pH} 7.0$ and $4^{\circ} \mathrm{C}$, and an X-ray film was exposed with the dried gel for 24-48 h for autoradiography.

Determination of the ATPase activity. The enzyme was assayed in an appropriate volume (see legends to the figures) at $37^{\circ} \mathrm{C}$ for $30 \mathrm{~min}$ in a medium containing $124 \mathrm{mM} \mathrm{KCl}, 100 \mathrm{mM}$ potassium-Hepes (pH 7.4), $2 \mathrm{mM}$ dithiothreitol, $0.054 \%$ $(w / v)$ Triton X-100, C.08\% (w/v) sonicated asolectin, $5 \mathrm{mM} \mathrm{MgCl}, 160 \mu \mathrm{M} \mathrm{CaCl}_{2}(0.22 \mu \mathrm{M}$ free $\left.\mathrm{Ca}^{2+}\right), 160 \mu \mathrm{M}$ EDTA, $240 \mu \mathrm{M}$ EGTA and 2 mM ATP (disodium salt) in the absence and presence of $120 \mathrm{nM}$ calmodulin.

Polyacrylamide gel electrophoresis and autoradiography. Slab gel electrophoresis on a continuous gradient $(5-20 \%, \mathrm{w} / \mathrm{v})$ polyacrylamide in the presence of $0.1 \%(w / v)$ sodium dodecyl sulfate or lithium dodecyl sulfate, modified from Laemmli [24], was run overnight $\left(10 \mathrm{~mA}\right.$ and $\left.4^{\circ} \mathrm{C}\right)$ at $\mathrm{pH}$ 8.3 for general purpose experiments, or at $\mathrm{pH} 7.0$ for those experiments identifying phosphorylated intermediate. Tha gel stained with Coomassie brilliant blue R-250 was dried on Whatman No. 1 paper and set in contact with an X-ray film for $24-48 \mathrm{~h}$ for ${ }^{32} \mathrm{P}$ detection, or $15-30$ days for ${ }^{14} \mathrm{C}$ detection. As standards, the following proteins of known molecular weight were used: myosin (200000), $\beta$-galactosidase (116200), phosphorylase $b(92500)$, bovine serum albumin $(66200)$, ovalbumin (45000), carbonic anhydrase (31000), soybean trypsin inhibitor (21500) and lysozyme (14400).

Batch binding studies with calmodulin-agarose gel. $4 \mathrm{ml}$ of calmodulin-agarose gel suspension (containing $1.6 \mathrm{mg}$ covalently bound calmodulin) was washed three times with $6 \mathrm{ml}$ of a solution containing $200 \mathrm{mM} \mathrm{KCl}, 50 \mathrm{mM}$ potassium-Hepes (pH 7.4), $50 \mu \mathrm{M} \mathrm{CaCl}_{2}$ and $0.02 \%$ (w/v) sodium azide and later equilibrated with $6 \mathrm{ml}$ of a buffer containing $300 \mathrm{~min} \mathrm{KCl}, 10 \mathrm{mM}$ potassium-Hepes (pH 7.4), $1 \mathrm{mM} \mathrm{MgCl}, 100 \mu \mathrm{M} \mathrm{CaCl}_{2}, 2 \mathrm{mM}$ dithiothreitol, $0.05 \%(w / v)$ Triton X-100 and $0.1 \%$ $(w / v)$ sonicated asolectin $\left(\mathrm{Ca}^{2+}\right.$ buffer). Thereafter, $0.5 \mathrm{ml}$ of purified enzyme $(25 \mu \mathrm{g}$ protein 
untreated or pretreated with $1 \mathrm{mM}$ DCCD for 36 ; min on ice) was added and allowed to remain in contact with the gel inder gentle stirring for 15 $\min$. The gel was centrifuged at $430 \times g_{\max }$ for 3 min and the supernatant (wash 1) was saved for electrophoresis. The gel was resuspended in the $\mathrm{Ca}^{2+}$ buffer, centrifuged once more and the "upernatant (wash 2) was saved for electrophoresis. The gel was then washed with $3 \mathrm{ml}$ of $300 \mathrm{mM} \mathrm{KCl}, 10$ $\mathrm{mM}$ potassium-Hepes, $2 \mathrm{mM}$ dithiothreitol, $0.05 \%$ $(w / v)$ Triton X-100, 0.1\% (w/v) sonicated asolectin, and 2 mM EDTA (EDTA buffer), the step was repeated and the combined supernatants (EDTA effluent) after centrifugation were saved for electrophoresis. The supernatants from washes 1 and 2 and from EDTA elutions were treated with $10 \%(w / v)$ trichloroacetic acid, centrifuged and the pellet was processed for electrophoresis. As a control, the calmodulin-agarose gel to which DCCD-treated enzyme had been added, was washed once more with the $\mathrm{Ca}^{2+}$ buifer and $25 \mu \mathrm{g}$ protein of untreated enzyme was applied as described above, to show that the binding capacity of the calmodulin-agarose gel itself was not decreased by the DCCD treatment employed.

Limited proteolysis of the $I^{14} C J D C C D$-labelled enzyme. $1.5 \mathrm{ml}$ of purified $\left(\mathrm{Ca}^{2+}+\mathrm{Mg}^{2+}\right)$-ATPase (72 $\mu \mathrm{g}$ protein) in a mediun containing $300 \mathrm{mM}$ $\mathrm{KCl}, 10 \mathrm{mM}$ potassium-Hepes (pH 7.4), $2 \mathrm{mM}$ dithiothreitol, $2 \mathrm{mM}$ EDTA, $0.05 \%$ (w/v) Triton $\mathrm{X}-100,0.1 \%(\mathrm{w} / \mathrm{v})$ sonicated phosphatidylcholine and $1 \%(\mathrm{v} / \mathrm{v}) N, N^{\prime}$-dimethylformamide was preincubated with $20 \mu \mathrm{M}\left[{ }^{14} \mathrm{C}\right] \mathrm{DCCD}(5 \mathrm{miCi}$. $\mathrm{mmol}^{-1}$ ) for $30 \mathrm{~min}$ at $4^{\circ} \mathrm{C}$. After the preincubation, $0.3-\mathrm{ml}$ aliquots $(14.4 \mu \mathrm{g}$ protein) were removed and precipitated with 10\% (w/v) trichloroacetic acid and the pellet was proce:ssed for electrophoresis and autoradiography. To the remaining $1.2 \mathrm{ml}$ mixture was added $50 \mu \mathrm{g}$ trypsin and, thereafter, $0.3-\mathrm{ml}$ aliquots were removed at 30 and $60 \mathrm{~min}$ intervals and precipitated with $10 \%(\mathrm{w} / \mathrm{v})$ trichloroacetic acid and the pellet was processed for electrophoresis and autoradiography.

Analytical procedures. Protein concentration was determined essentially by the method of Lowry et al. [25] after protein precipitation by $10 \%(\mathrm{w} / \mathrm{v})$ trichloroacetic acid, using bovine serum albumin as a standard. When determination of the concentration of protein in the band of $\mathrm{CCa}^{2+}+$
$\mathrm{Mg}^{2+}$ )-ATPase in the electrophoresis gel was required, different concentrations of bovine serum albumin were included in the same gel, stained with Coomassie brilliant blue R-250, measured on the densitometer at $650 \mathrm{~nm}$ and the area under the peak was integrated with a planimeter and used for calibration. Linearity between the densitometric intensity of the protein band in the gel and the amount of protein was demonstrated up to $20 \mu \mathrm{g}$ protein. The inorganic phosphate produced during hydrolysis of ATP was determined colorimetrically [26]. Calculation of the concentration of free calcium ion was by the program detailed by Goldstein [27], modified as previously described [22].

\section{Results}

$\int^{14} \mathrm{ClDCCD}$ labelling and inhibition of the $1 \mathrm{Ca}^{2+}$ $+M^{2+}$ ).ATPase

Incubation of the purified $\left(\mathrm{Ca}^{2+}+\mathrm{Mg}^{2+}\right)$ ATPase from human erythrocytes with $\left[{ }^{14} \mathrm{C}\right]$ DCCD results in the formation of a single ${ }^{14} \mathrm{C}$ labelled polypeptide (Fig. 1, track C) of a molecular weight $(136000)$ identical to that of the purified enzyme stained with Coomassie blue (Fig. 1. track B). However, the amount of $\left[{ }^{14} \mathrm{C}\right] \mathrm{DCCD}$ labeiled protein able to penetrate into the electrophoretic gel could be as much as 50\% lower than the untreated enzyme depending on the DCCD conc entration used for labelling, indicating that DCC.D-treatment could result in irreversible aggregation of part of the $\left(\mathrm{Ca}^{2+}+\mathrm{Mg}^{2+}\right) \cdot$ ATPase moliscules. Fig. 1 also shows that DCCD-treatment of the $\left(\mathrm{Ca}^{2+}+\mathrm{Mg}^{2+}\right)$-ATPase molecule results in inhibition of the aspartylphosphate intermediate formation (Fig. 1, compare tracks D and E).

The ATP hydrolytic activity of the enzyme was inhibited by DCCD in a concentration- and timedependent manner, both in the absence and in the presence of calmodulin (Fig. 2).

Calmodulin increases the labelling of the $\left(\mathrm{Ca}^{2+}+\right.$ $\mathrm{Mg}^{2+}$ )-ATPase by DCCD

The number of $\left[{ }^{14} \mathrm{C}\right] \mathrm{DCCD}$ molecules covalently bound to each molecule of $\left(\mathrm{Ca}^{2+}+\mathrm{Mg}^{2+}\right)$ ATPase was directly determined in the absence and presence of calmodulin with different concentrations of DCCD in the assay system. Fig. 3 shows a plot of the $\left[{ }^{14} \mathrm{C}\right] \mathrm{DCCD} /\left(\mathrm{Ca}^{2+}+\mathrm{Mg}^{2+}\right)$. 
ATPase $(\mathrm{mol} / \mathrm{mol})$ ratio versus the percent of ATPase activity remaining in the system. The maximum number of $\left[{ }^{14} \mathrm{C}\right] \mathrm{DCCD}$ molecules bound per molecule of ATPase was approx. 5 (in the absence of calmodulin) and approx. 12 (in the presence of calmodulin) when 70-75\% of the en-

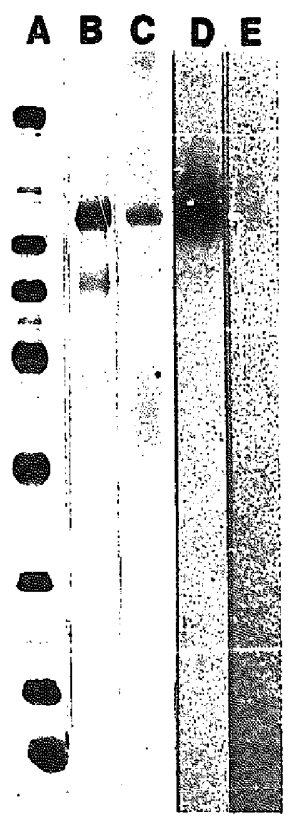

Fig. 1. $\left[{ }^{14} \mathrm{C}\right] \mathrm{DCCD}$ labelling of the purified $\left(\mathrm{Ca}^{2+}+\mathrm{Mg}^{2+}\right)$ ATPase and inhibition of the ${ }^{32}$ P.labelled phosphorylated intermediate. Track A, Ccomassie blue staining of molecular weight markers as described in Material and Methods. Tracks $B$ and $C$, the purified enzyme ( $72 \mu \mathrm{g}$ protein) was incubated for $30 \mathrm{~min}$ (on ice) in $1.2 \mathrm{ml}$ of a medium containing $300 \mathrm{mM}$ $\mathrm{KCl}, 10 \mathrm{mM}$ potassium-Hepes, (pH 7.4), $2 \mathrm{mM}$ dithiothreitol, $2 m$ EDTA, $0.05 \%(w / v)$ Triton X-100, $0.1 \%(w / v)$ sonicated phosphatidylcholine and $1 \%(v / v) N, N^{\prime}$-dimethylformarnide, in the presence of $20 \mu \mathrm{M}$ DCCD containing $\left[^{14} \mathrm{C}\right] \mathrm{DCCD}\left(5 \mathrm{mCi} \cdot \mathrm{mmol}^{-1}\right)$. After the incubation, $0.3 \mathrm{ml}$ of the irixture (containing $18 \mu \mathrm{g}$ protein) was precipitated with $10 \%(w / v)$ trichloroacetic acid and processed for electrophoresis at pH 8.3, followed by staining with Coomassie blue (track B) and autoradiography (track C) as described in Materials and Methods. Tracks D and E, the purified enzyme $(5.2 \mu \mathrm{g}$ protein) was incubated for $15 \mathrm{~s}$ at $4^{\circ} \mathrm{C}$ in $0.2 \mathrm{ml}$ of a medium containing $40 \mathrm{mM}$ potassium-Hepes, $0.1 \mathrm{mM} \mathrm{MgCl}, 0.92 \mathrm{mM}$ $\mathrm{CaCl}_{z}, 2 \mathrm{mM}$ dithiothreitol, $0.054 \%$ (w/v) Triton X-100, 0.1\% (w/v) sonicated asolectin, $10 \mu \mathrm{M}$ ATP containing $\left[\gamma_{-}{ }^{32}\right.$ P]ATP (28.9 (i. $\left.\mathrm{mmol}^{-1}\right)$ in the absence (track D) or presence (track E) of $0.5 \mathrm{mM}$ DCCD. After the incubation and precipitation with $10 \%(w / v)$ trichloroacetic acid, the protein was processed for electrophoresis at $\mathbf{p H} \mathbf{7 . 0}$ and autoradiography was cartied out.

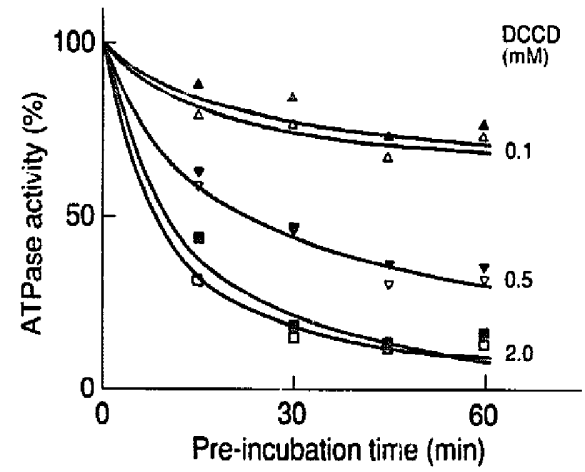

Fig. 2. Effect of incubation time and different concentrations of DCCD on the activity of the purified $\left(\mathrm{Ca}^{2+}+\mathrm{Mg}^{2+}\right)$ ATPase. Purified enzyme ( $3.7 \mu \mathrm{g}$ protein) was incubated for the indicated perind of time in the presence of the indicated concentration of DCCD at $37^{\circ} \mathrm{C}$ in $0.94 \mathrm{ml}$ of a medium containing $124 \mathrm{mM} \mathrm{KCl}, 100 \mathrm{mM}$ Tris- $\mathrm{HCl}, 100 \mathrm{mM}$ potassium-Hepes (pH 7.4), $5 \mathrm{mM} \mathrm{MgCl}, 160 \mu \mathrm{M}$ EDTA, $160 \mu \mathrm{M}$ EGTA, $160 \mu \mathrm{M} \mathrm{CaCl}, 2 \mathrm{mM}$ dithiothreitol, 0.054\% (w/v) Triton X-100, $0.1 \%(" / v)$ sonicated asolectin and $1 \%(v / v)$ $N, N^{\prime}$-dimethylformamide in the absence (open symbols) or presence (closed symbols) of $120 \mathrm{n}^{\mathrm{N}}$ calmodulin. The reaction was started by addition of $2.4 \mathrm{mM} \mathrm{ATP} \mathrm{(sodium} \mathrm{salt)} \mathrm{and}$ incubation continued for an extra $60 \mathrm{~min}$. The percent decrease of activity during the $60 \mathrm{~min}$ of assay was subtracted from the total inactivation. The $100 \%$ activity at zero time of preincubation was 1.5 and $2.3 \mu \mathrm{mol}^{-} \mathrm{min}^{-1} \cdot \mathrm{mg} \mathrm{protcin}^{-1}$ in the absence and presence of calmodulin, respectively.

zymatic activity of the enzyme was inhibited by DCCD. Since the innibition of the ATPase activity appears to increase linearly with the number of DCCD molecules bound to the enzyme, the number of DCCD molecules required to attain $100 \%$ inhibition of the enzyme was calculated by extrapolation. This number was approx. 6.7 in the absence of calmodulin and approx. 13.1 in its presence.

DCCD affects the binding of calmodulin to the $\left(\mathrm{Ca}^{2+}+\mathrm{Mg}^{2+}\right)-$ ATPase

To determine whether or not the treatment of purified $\left(\mathrm{Ca}^{2+}+\mathrm{Mg}^{2+}\right)$-ATPase with DCCD affects its capacity to bind calmodulin, both DCCD-treated and untreated enzymes were preincubated with a calmodulin-agarose gel in the presence of calcium ion. The amount of enzyme remaining unbound in the supernatant was determined by electrophoresis. The bound enzyme was eluted thereafter with EDTA from the 
calmodulin-agarose gel and was also determined by electrophoresis. Fig. 4 presents a typical experiment which shows that the untreated cnzyme (track 1 , panel A) bound $100 \%$ to the calmodulin-agarose gel in the presence of calcium ion, and therefore

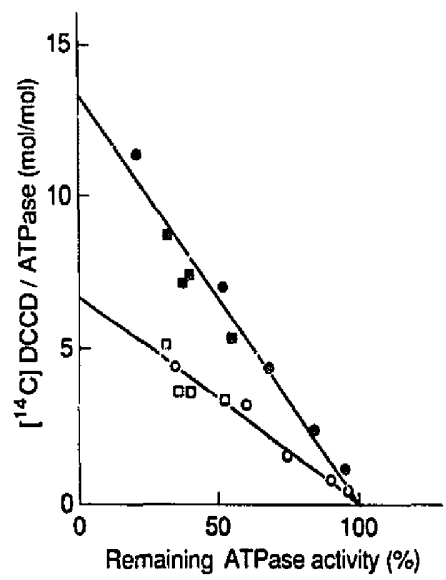

Fig. 3. Stoichiometry of mol of $\left[{ }^{14} \mathrm{C}\right] \mathrm{DCCD}$-bound per mol of $\left(\mathrm{Ca}^{2+}+\mathrm{Mg}^{2+}\right)$-ATPase in the absence and presence of caimudulin. Purified enzyme (20 $\mathrm{\mu g}$ protein) was assayed at $37^{\circ} \mathrm{C}$ for $30 \mathrm{~min}$ in a total volume of $5.0 \mathrm{ml}$ in a medium containing $124 \mathrm{mM} \mathrm{KCl}, 100 \mathrm{mM}$ potassium-Hepes ( $\mathrm{pH}$ 7.4), 5 $\mathrm{mM} \mathrm{MgCl} 2,160 \mu \mathrm{M} \mathrm{CaCl}_{2}, 160 \mu \mathrm{M}$ EDTA, $240 \mu \mathrm{M}$ EGTA, $2 \mathrm{mM}$ dithiothreitol, $0.054 \%(w / v)$ Triton $X-100,0.08 \%(w / v)$ asolectin, $2 \mathrm{mM} \mathrm{ATP}$ and $1.2 \%(v / v) ~ N, N^{\prime}$-dimethylformamide in the absence (open symbols) and presence (closed symols) of $120 \mathrm{nM}$ calmodulin and appropriate concentrations of DCCD (from 0 to $2.4 \mathrm{mM}$ containing $5 \mathrm{mCi} \cdot \mathrm{mmol}^{-1}$ $\left.\left[{ }^{14} \mathrm{C}\right] \mathrm{DCCD}\right)$ to give different degrees of inactivation of the enzyme. The reaction was terminated by addition of $10 \%$ (w/v) trichloroacetic acid, and inorganic phosphate released to the medium was determined as described in Materials and Methods. The protein in the pellet was processed for electrophoresis at pH 8.3 as descrited in Materials and Methods. After electrophoresis and staining of the get with Coomassie blue, the amount of protein in the band of molecular weight 136000 corresponding to the $\left(\mathrm{Ca}^{2+}+\mathrm{Mg}^{2+}\right)$-ATPase was determined planimetrically using a calibration of the integrated asea of the densitometric intensity of the band at $650 \mathrm{~nm}$ of different concentrations of bovine serum albumin. The 136000 band was cut, bleached in $30 \%(\mathrm{v} / \mathrm{v}) \mathrm{H}_{2} \mathrm{O}_{2}$ and the levels of ${ }^{14} \mathrm{C}$ were measured by liquid scintiliation counting in Aquasol $^{\text {th }}$. Appropriate blanks wert prepared with similar pieces of unlabelled gels to determine background levels of radiation. A plot is presented of the percent ATPase activity remaining versus the $\left[{ }^{14} \mathrm{C}\right] \mathrm{DCCD} /\left(\mathrm{Ca}^{2+}+\mathrm{Mg}^{2+}\right)$-ATPase $(\mathrm{mol} / \mathrm{mol})$ ratio determined. The theoretical maximum stoichiometry is the extrapolated value when the ATPase activity is zero. Circles and square symbols correspond to experiments performed with different batches of enzyme.
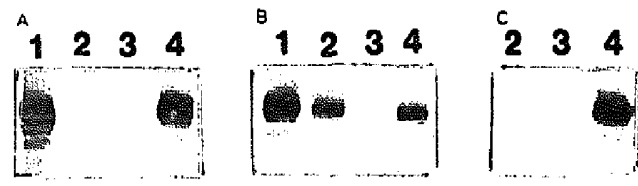

Fig. 4. Effect of DCCD on the binding of the purified $\left(\mathrm{Ca}^{2+}+\right.$ $\mathrm{Mg}^{2+}$ )-ATPase to a calmodulin-agarose gel. Purified enzyme ( $25 \mu \mathrm{g}$ protein) was incubated in the absence (panels $A$ and $C$ ) or presence (panel B) of $1 \mathrm{mM} \mathrm{DCCD}$ for $30 \mathrm{~min}$ (on ice) in $0.5 \mathrm{ml}$ of a buffer containing $300 \mathrm{mM} \mathrm{KCl}, 10 \mathrm{mM}$ potassiumHepes (pH 7.4), $2 \mathrm{mM}$ dithiothreitol, $2 \mathrm{mM}$ EDTA, 0.05\% $(w / v)$ Triton X-100,0.1\% (w/v) asolectin and $1 \%(v / v)$ $N, N^{\prime}$-dimethylformamide. The enzyme was then bound to a suspension of calmodulin-agarose gel as discussed in Materials and Methods in a buffer containing $50 \mu \mathrm{M} \mathrm{CaCl}$, washed several times with the same $\mathrm{Ca}^{2+}$ buffer and then eluted in a buffer containing $2 \mathrm{mM}$ EDTA. The unbound and the eDTAeluted enzyme were precipitited with $10 \%(w / v)$ trichloroacetic acid and processed for electrophoresis ( $\mathrm{pH} \mathrm{8.3).} \mathrm{Track} \mathrm{1,}$ before binding to the calmodulin-agarose gel. Track 2, cnzyme in first $\mathrm{Ca}^{2+}$ buffer supernatant (unbound). Tracks 3, enzyme in second $\mathrm{Ca}^{2+}$ buffer supernatant (unbound). Tracks 4, enzyme eluted with EDTA buffer (bound). In panel $C$ the calmodulin-agarose gel was pretreated with the same amount of DCCD that was used in panel B befors the binding of non-treated enzyme. Note that the binding capacity of the calmodulin-agarose gel was not affected by DCCD treatment.

was not present in the supernatant (tracks 2 and 3, panel A). However, it was fully recovered after EDTA elution (track 4, panel A). In contrast, in panel $B$ of the same figure, it is shown that the DCCD-treated enzyme (track 1, panel B) incubated with the calmodulin-agarose gel in the presence of calcium ion was recovered partially unbound (approx. 50\%) in the supernatant (track 2, panel B). The other 50\% of the enzyme was eluted with EDTA (track 4, panel B). To ascertain that $D C C D$ does not inactivate the calmodulin covalently bound to the calmodulin-agarose gel, the same gel as that used in the experiment presented in panel B was used to bind a batch of untreated enzyme. The results presented in panel $\mathrm{C}$ of Fig. 4 show that in the presence of $\mathrm{Ca}^{2+}$, $100 \%$ of the enzyme bound to the calmodulinagarose gel (note absence of enzyme in tracks 2 and 3 of panel $C$ ) and was fully recovered after EDTA elution (track 4, panel C), as expected.

Identification of trypsin fragments of the $\mathrm{CCa}^{2+}+$ $M g^{2+}$-ATPase molecule labelled with $I^{14} \mathrm{ClDCCD}$

Partial trypsinization of the $\left[{ }^{14} \mathrm{C}\right] \mathrm{DCCD}$ labelled $\left(\mathrm{Ca}^{2+}+\mathrm{Mg}^{2+}\right)$-ATPase could identify 

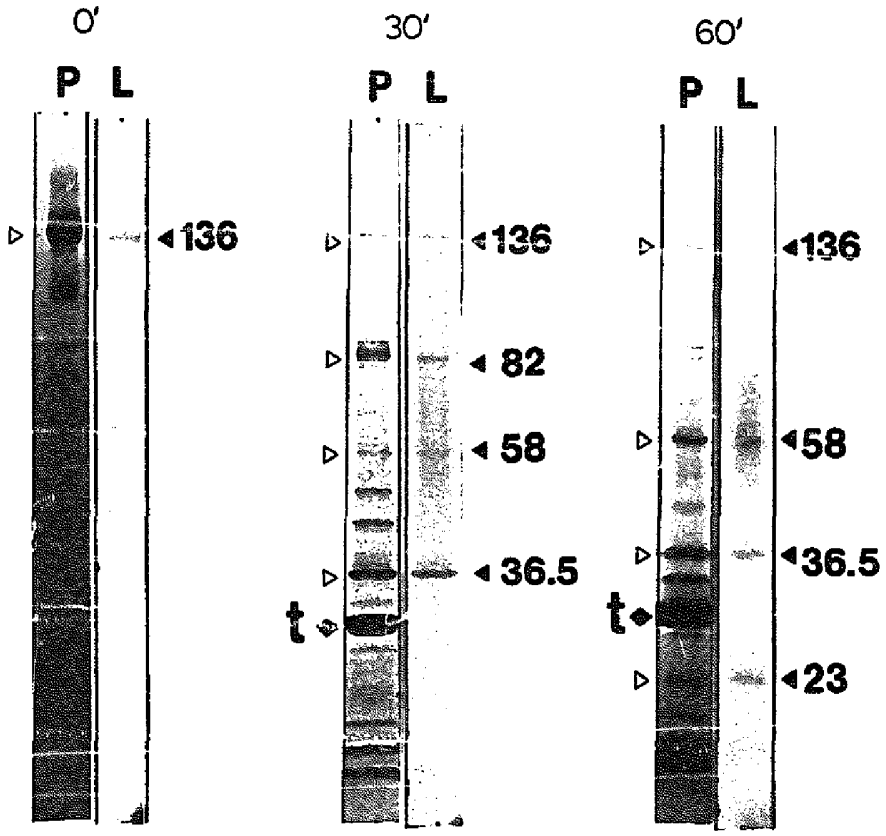

Fig. 5. Partial trypsinization of the $\left[{ }^{14} \mathrm{C}\right] \mathrm{DCCD}-\mathrm{treated}\left(\mathrm{Ca}^{2+}+\mathrm{Mg}^{2+}\right)$-ATPase. Purified enzyme (72 $\mu \mathrm{g}$ protein) was inc ubated for $30 \mathrm{~min}$ on ice with $20 \mu \mathrm{M}\left[{ }^{14} \mathrm{C} D C C D\left(5 \mathrm{mCi} \cdot \mathrm{mmol}^{-1}\right)\right.$ in a total volume of $1.2 \mathrm{ml}$ of a medium containing $300 \mathrm{mM} \mathrm{KCl}, 10 \mathrm{mM}$ potassium-Hepes (pH 7.4), $2 \mathrm{mM}$ dithiothreitol, $2 \mathrm{mM}$ EDTA, $0.05 \%$ (w/v) Triton X-100, 0.1\% (w/v) sonicated phosphatidylcholine and $5 \%(\mathrm{v} / \mathrm{v}) \mathrm{N}, N^{\prime}$-dimethylformamide. After this treatment, a $0.3-\mathrm{ml}$ aliquot (18 $\mu \mathrm{g}$ protein) was taken, precipitated with $10 \%$ $(w / v)$ trichloroacetic acid and processed for electrophoresis (zero time). To the rest of the mixture was added $50 \mu \mathrm{g}$ trypsin and the preincubation was continued at $0^{\circ} \mathrm{C}$ for the indicated period of time. $0.3 \mathrm{ml}$ of the mixture (18 $\mu \mathrm{g}$ protein) was taken, precipitated with $10 \%(w / v)$ trichloroacetic acid and processed for electrophoresis. Panels labelled $0^{\prime}, 30^{\prime}$ and $60^{\prime}$ indicate the time in minutes of digestion in the presence of trypsin. Tracks $P$ labelled show the protein pattern stained with Coomassie blue. Tracks $L$ labelled show the autoradiograph of the ${ }^{14} \mathrm{C}$-labelled fragments. Arrows labelled $t$ indicate, the trypsin band. The ${ }^{14} \mathrm{C}$-labelled polypeptides and their corresponding molecular weights $\left(\times 10^{3}\right)$ are indicated with black arrowheads, and the corresponding Coomassie blue-stained polypeptides are indicated with white arrowheads.

general regions of the enzyme where DCCD binds. Fig. 5 shows that the native $\left[{ }^{14} \mathrm{C}\right] \mathrm{DCCD}$-labelled enzyme of molecular weight 136000 is progressively hyrolyzed to a series of $\left[{ }^{14} \mathrm{C}\right] \mathrm{DCCD}$-labelled fragments. Tracks marked $P$ show the protein patterns of control enzyme and partially proteolyzed $\left(\mathrm{Ca}^{2+}+\mathrm{Mg}^{2+}\right)$-ATPase at $30 \mathrm{~min}$ and 60 min, while those marked $L$ show the autcradiographic pattern of the ${ }^{14} \mathrm{C}$-labelled polypeptides. It is shown that the intact $\left[{ }^{14} \mathrm{C}\right] \mathrm{DCCD}$-labelled ATPase (molccular weight 136000) is progressively fragmented to $\left[{ }^{14} \mathrm{C}\right] \mathrm{DCCD}$-labelled fragments with molecular weights of 82000,58000 and 36500 after $30 \mathrm{~min}$ and three major ${ }^{14} \mathrm{C}$ - labelled fragments with molecular weights of 58000,36500 and 23000 after $60 \mathrm{~min}$.

\section{Discussion}

The interaction of DCCD with carboxyl group(s) of the $\left(\mathrm{Ca}^{2+}+\mathrm{Mg}^{2+}\right)$-ATPase can result in the formation of dicyclohexyl- $O$-acylisourea derivative intermediate(s). This intermediate(s) can further result in either (i) intramolecular or intermolecular crosslinking of the enzyme due to nucleophilic attack by amino groups and the release of dicyclohexylurea or (ii) the formation of stable dicyclohexyl- $N$-acylurea derivative(s) of the 
enzyme. These interactions are more likely to occur in hydrophobic domains of the enzyme since the dicyclohexyl- $O$-acylisourea derivative intermediate(s) is highly susceptible to nucleophilic attack by water and is, therefore, able to regenerate a non-modified enzyme [1]. Our results show that using $\left[{ }^{14} \mathrm{C}\right] \mathrm{DCCD}$ it is possible to detect a stable ${ }^{14} \mathrm{C}$-labelled $\mathrm{Ca}^{2+}$-ATPase, indicative of the formation of dicyclohexyl- $\mathrm{N}$-acylurea derivative(s) of the enzyme (Fig. 1, 3 and 5). However, our experiments also show that DCCD treatment results in a significant decrease in the number of ATPase molecules able to penetrate the polyacrylamide gel (results not shown), suggesting that intermolecular crosslinked complexes of high molecular weight are formed as well.

As in the case of the $\left(\mathrm{Ca}^{2+}+\mathrm{Mg}^{2+}\right)$-ATPase from sarcoplasmic reticulum [15], DCCD also inhibits the formation of the aspartylphosphate intermediate of the erythrocyte $\left(\mathrm{Ca}^{2+}+\mathrm{Mg}^{2+}\right)$ ATPase (see Fig. 1). We have shown previously [16] that $\mathrm{Ca}^{2+}$ does not prevent inhibition of the erythrocyte $\left(\mathrm{Ca}^{2+}+\mathrm{Mg}^{2+}\right)$-ATPase induced by DCCD, but rather increases its inhibitory potency. Therefore, inhibition of the phosphorylated intermediate formation could be the result of a direct interaction of DCCD with the ATP binding domain(s) and/or the phosphorylating site itself rather than interaction with the $\mathrm{Ca}^{2+}$-binding sites.

We have demonstrated (Fig. 3) that the erythrocyte $\left(\mathrm{Ca}^{2+}+\mathrm{Mg}^{2+}\right)$-ATPase interacts with DCCD at multiple sites. However, the number of moles of DCCD to each mole of $\mathrm{Ca}^{2+}$-ATPase experimentally, should be considered as only a minimum value, since hydrolysis of part of the dicyclohexyl- $O$-acylisourea derivative intermediate(s) could not be excluded, particularly in hydrophilic regions of the enzyme. Calmodulin also has a profound effect on the stoichiometry of DCCD bound to each molecule of $\left(\mathrm{Ca}^{2+}+\right.$ $\mathrm{Mg}^{2+}$ )-ATPase (see Fig. 3). The doubling of the number of residues susceptible to interaction with DCCD in the calmodulin- $\left(\mathrm{Ca}^{2+}+\mathrm{Mg}^{2+}\right)$-ATPase complex suggests that significant comformational changes exposing carboxylic groups (from hydrophobic domains) takes place when the $\left(\mathrm{Ca}^{2+}+\right.$ $\mathrm{Mg}^{2+}$ )-ATPase interacts with calmodulin. These results are in agreement with our earlier observations that calmodulin favors the $\mathrm{Ca}^{2+}$-dependent inactivation of the $\left(\mathrm{Ca}^{2+}+\mathrm{Mg}^{2+}\right)$-ATPase induced by DCCD in the assay system, which includes the presence of ATP [16]. However, Fig. 2 shows that when the enzyme was preincubated in the presence of DCCD without ATP, calmodulin has little effect on the inactivation occurring during preincubation. These results also suggest that binding of ATP to the enzyme could modify its reactivity to $D C C D$. In fact, we have demonstrated that in the absence of ATP the number of DCCD-reactive sites was lower (results not shown). The calmodulin-binding domain of the erythrocyte $\left(\mathrm{Ca}^{2+}+\mathrm{Mg}^{2+}\right)$-ATPase is believed to have a high degree of hydrophobicity, since it interacts with a highly hydrophobic region of the $\mathrm{Ca}^{2+}$. calmodulin complex [28]. Therefore, this region of the enzymc could be highly reactive to the hydrophobic DCCD molecule. In our earlier work we observed that $D C C D$ selectively decreased the stimulation induced by calmodulin in the $\mathrm{Ca}^{2+}+$ $\mathrm{Mg}^{2+}$ )-ATPase activity without significant inactivation of calmodulin molecules [16], suggesting that the calmodulin-binding domain of the enzyme was directly or indirectiy modified by DCCD. We have now shown (Fig. 4) than when the $\mathrm{Ca}^{2+}{ }_{-A}$ TTPase was treated with DCCD this significantly decreased its capacity to bind to a calmodulin-agarose gel, as would be expected if the calmodulin-binding domain is modified by DCCD. However, modification of the calmodulinbinding domain could be an indirect effect of binding of DCCD to the enzyme. Therefore, we have tried to obtain further evidence for the direct interaction of DCCD with the calmodulin-binding domain of the enzyme.

Partial trypsinization of a $\left[{ }^{14} \mathrm{C}\right] \mathrm{DCCD}$-labelled enzyme could identify general regions where DCCD interacts. Our experiments on trypsin fragmentation of the ${ }^{14} \mathrm{C}$-labelled enzyme show that a $23 \mathrm{kDa}{ }^{14} \mathrm{C}$-labelled fragment of molecular weight 23000 was produced (Fig. 5). Similar partial trypsinization of the $\left(\mathrm{Ca}^{2+}+\mathrm{Mg}^{2+}\right)$-ATPase by Zurini et al. [29] has previously identified that a fragment of 25000 contained the calmudulin-binding domain of the enzyme by its crosslinking to $\left[{ }^{125}\right.$ I] iodoazidocalmodulin.

Similarly, the region of the $\left(\mathrm{Ca}^{2+}+\mathrm{Mg}^{2+}\right)$. ATPase spanning the plasma membrane is expected to be highly hydrophobic, making it easy 
for DCCD to react with carboxyl $\varepsilon^{*}$ oup(s) in that domain. We also have found a ${ }^{14} \mathrm{C}$-labelled fragment of molecular weight 36500 (Fig. 5) that appears to correspond to a previously identified 33500 fragment with a high degree of hydrophobicity as confirmed by its reactivity to the photoactive reagent 3-(trifluoromethyl)-3-( $m$ - $\left[{ }^{125} 1\right]$-iodophenyl)diazirine used by them [29]. Therefore, our results suggest that both the calmodulin-binding domain and the membrane-spanning domain are regions of the $\mathrm{Ca}^{2+}$ pump able to interact directly with this hydrophobic carbodiimide. The small differences in molecular weight of fragments corresponding to the calmodulin-binding domain and membrane-spanning domain previously described by Zurini et al. [29], and the ${ }^{14} \mathrm{C}$-labelled fragments identified by us, could be due to the differences in resolution of the 5-20\% linear polyacrylamide gradient gel used here and a $7 \%$ potyacrylamide gel used in Ref. 29.

As in the case of the sarcoplasmic reticulum $\mathrm{Ca}^{2+}$ pump [30], identification of general regions of the erythrocyte enzyme able to react with carbodiimides and the effects of these interactions on different enzyme ligands could be of great importance for future understanding of the mode of operation of this enzyme.

\section{Acknowledg(ments}

This work was supported by The National Science and Engineering Research Council, The Meditial Research Council of Canada and The Canatian Heart Foundation. O.O.O. is a CIDA/NSERC Research Associate.

\section{References}

1 Azzi, A. Casey, R.P. and Nalecz M.J. (1984) Biochim. Biophys. Acta 768, 209-226.

2 Beechey, R.B., Roberison, A.M., Holloway, C.T. and Knight, J.G. (1967) Biochemistry 6, 3867-3879.
3 Nelson, N., Eytan, E., Notsani, B.-E., Sigrit, H.. Sigrit-Nelson, K. and Gitter, C. (1977) Proc. Natl. Acad. Sci, USA $74,2575-2370$.

4 Casey, R.P., Thelen, M. and Azzi, A. (1979) Biochem. Biophys. Res. Commun. 87, 1044-1051.

5 Casey, R.P., Thelen, M. and Azzi, A. (1980) J. Biol. Chem. 255, 3994-4000.

6 Fillingam. R.H. (1980) Annu. Rev. Biochem. 49, 1079-1113.

7 Phelps, D.C. and Hatefi, Y. (1981) J. Biol. Chem. 256, 8217-8221.

8 Pennington, R.M. and Fisher, R.R. (1981) J. Biol. Chem. 256, 8963-8969.

9 Lenaz, G.. Degii-Esposti, M. and Parenti-Castelli, G. (1982) Rinchem. Biophys. Res. Commun. 105, 589-595.

10 Beattie, D.S. and Yiln!oho. A. (1982) J. Biol. Chem. 257. 14745-14752.

ii Price, B.D. and Brand, M.D. (1982) Biochem. J. 206. 419-421.

12 Pick, U. and Racker. E. (1979) Biochemistry 18, $108-113$.

13 Murphy, A.J. (1981) J. Biol. Chem. 256, 12046-12050.

14 Chadwick. C.C. and Thomas, E.W. (1983) Biochim. Biophys. Acta 827, 419-423.

is Scolano, H.ivi., Bamabin, H., Lewis, D. and Inkii, G. (1985) Biochenistry 24, 1025-1029.

16 Villalobo, A., Harris, J.W. and Roufogalis, B.D. (1986) Biochim. Biophys. Acta 858, 188-194.

17 Schoner, W, and Schmidt, H. (1969) FEBS Lett. 5, 285-287.

18 Robinson, J.D. (1974) FEBS Lett. 38, 325-328.

19 Yamaguchi, M., Sakamoto, J. and Tonomura, Y. (1983) Curr. Top. Membr. Transp. 19, 203-217.

20 Gorga, F.R. (1985) Biochemistry 24, 6783-6788.

21 Pedemonte, C.H. and Kaplan, J.H. (1986) J. Biol. Chem. 261, 3632-3639.

22 Villalobo, A., Brown, L. and Roufogalis, B.D. (1986) Biochim. Biophys. Acta 854. 9-20.

23 Villalobo, A. and Roufogalis, B.D. (1986) J. Membr. Biol. 93, 24? 258.

24 Laemmli, U.K. (1970) Nature (London) 227, 680-685.

25 Lowry, O.H., Rosebrough, N.J., Farr, A.L. and Randall, R.J. (1951) J. Biol. Chem. 193, 265-275.

26 Raess, B.U. and Vincenzi, F.F. (1980) J. Pharmacol, Methods 4, 273-283.

27 Goldstein, D. (1979) Biophys. J. 26, 235-242.

28 Klee, C.B. and Vanaman, T.C. (1982) Adv. Prot. Chem. 35. 213-321.

29 Zurini, M., Krebs, J., Penniston. J.T. and Carafoli, E. (1984) J. Biol. Chem. 259, 618-627.

30 Garcia de Ancos, J. and Inesi, G. (1988) Biochemistry 27, 1793-1803. 